\title{
Knowing-with-snow in an outdoor kindergarten
}

\author{
Pernille Bartnæs` \& Anne Myrstad \\ UiT The Arctic University of Norway, Norway
}

\begin{abstract}
This article highlights how reciprocal relationships between children and the environment can contribute to exploring understanding of children's learning in the outdoor environment. We draw on data from a kindergarten in the northern part of Norway, where we have carried out fieldwork three hours a week from October to mid-May. During this period, the outdoor area was covered with snow of varying qualities. Snow and weather conditions are included as elements in a relational understanding, in which the environment is understood as open and dynamic - an interaction between past and present, between geography, materiality, people and the 'more-than-human'. The learner and the environment are understood as an indivisible process, where different elements exercise a reciprocal influence on each other. Using Ingold's concept of correspondence, we explore how children learn by being within and with the world. The article is a contribution to creating a nuanced understanding of children's learning and the educator's role within an outdoor environment in kindergarten practice.
\end{abstract}

Keywords: children; correspondance; kindergarten; outdoor learning

\section{Sammendrag}

I denne artikkelen vil vi løfte frem hvordan gjensidige relasjoner mellom barn og omgivelser kan bidra til å utforske forståelser av barns læring i barnehagens uteområde. Vi tar utgangspunkt i data fra en barnehage i den nordlige delen av Norge, hvor vi har gjort feltarbeid tre timer i uken fra oktober til midten av mai måned. Uteområdet var i denne perioden dekket av snø med ulike kvaliteter. Snø og værforhold inngår som elementer i en relasjonell forståelse, hvor omgivelsene blir forstått som åpent og dynamisk - en sammenkastning mellom fortid og nåtid, mellom geografi, materialitet, mennesker og 'more-than-human'. Den lærende og omgivelsene forstås som en udelelig prosess som virker sammen, hvor ulike elementer gjensidig påvirker hverandre. Ved anvendelse av Ingolds begrep korrespondanse utforsker vi hvordan barn lærer ved å være $i$ og med verden. Artikkelen er et bidrag til å nyansere forståelsen av barns læring og pedagogens rolle i utendørs omgivelser i barnehagens praksis.

\section{Nøkkelord: barn; barnehage; korrespondanse; utendørs lering}

Received: March, 2021; Accepted: October, 2021; Published: January, 2022

\footnotetext{
^Correspondence: Pernille Bartnæs, e-mail: pernille.e.bartnas@uit.no
}

(C) 2022 P. Bartnæs \& A. Myrstad. This is an Open Access article distributed under the terms of the Creative Commons Attribution 4.0 International License (https://creativecommons.org/licenses/BY/4.0/), allowing third parties to copy and redistribute the material in any medium or format and to remix, transform, and build upon the material for any purpose, even commercially, provided the original work is properly cited and states its license.

Citation: P. Bartnces $\mathcal{E}$ A. Myrstad. "Knowing-with-snow in an outdoor kindergarten» fournal for Research in Arts and Sports Education, Special issue: Friluftsliv, dannelse, lcering og didaktikk, Vol. 6(1), 2022, pp. 76-91. 


\section{Vignette}

It is mid-November. Some half-metre of loose and fluffy snow is lying on the ground. An extremely cold period has led to the formation of snow crystals of about 1-2 cm in the top layer of snow. Vilde (4 years old) and the researcher, Pernille, are walking together along a trodden-down path through the snow in the kindergarten's outdoor area.Vilde stops and looks down at the big snow crystals. She sits down, leans forward, and puts out her tongue towards the topmost layer of snow. The snow crystals attach themselves to her tongue. She smacks her lips and says: 'I think that's good. Do you know what a snow crystal tastes like?'

\section{Introduction}

What does a snow crystal taste like? Children engage with the world through exploring: tasting, climbing, crawling, creeping, sitting down and rolling around, smelling, and touching (Cele, 2019; Änggård, 2016). This sort of involvement provides children with direct experiences of their environments, which serves to create meaning (Ingold, 2000). In the opening vignette, Vilde experienced the taste of snow crystals through her sensuous encounter with snow. This article considers such encounters as reciprocal relationships in which the child and the environments are understood as inseparable processes that work together. This is a contribution to depicting how knowledge emerges through all relationships of which children are a part. The article examines the question of how children's encounters in and with their surroundings can be understood and valued as learning processes.

To shed light on this question, we will focus on children's direct encounters with their surroundings in the outside areas of the kindergarten. Learning with and in addresses the children's ways of being in the world (Ingold, 2000; Myrstad \& Sverdrup, 2019; Springgay \& Truman, 2018), in which the learner is entangled with diverse aspects of their social, physical and (im-)material surroundings through large and small movements. We refer to the interaction of a kindergarten child with a snowy landscape: how their feet move in the snow at the same time as the snow moves the feet, or - as in the above vignette - how the snow crystals touch the tongue, and the tongue touches the snow crystals. Tim Ingold's concept of 'correspondence' is used as a theoretical tool to highlight this kind of reciprocal relationship between children and their environments (2013). In a reciprocal relationship, changing environments and weather conditions will form nuances of significance for how children's knowledge emerges with nature as a 'co-teacher' (Blenkinsop, 2018).

Our empirical basis is derived from an outdoor kindergarten in the northern, Arctic region of Norway. In these surroundings, kindergarten children and staff spend time outdoors, irrespective of weather and season. The area is snow-covered for several months, usually from the end of October until the middle of May. After heavy snowfalls, the landscape is transformed into a landscape of snow in which former nuances, details, and points of reference on the ground vanish. The snowscape can be regarded metaphorically as a clean sheet (Myrstad et al., 2020). Taken literally, the snow defines mobility, visibility, and accessibility for activities (Eira et al., 2018). We will 


\section{P. Bartnces \& A. Myrstad}

initially refer to examples of how kindergarten children get involved in, explore, and learn in this snowscape. Subsequently we will discuss how educators can appreciate and draw attention to such processes.

\section{Background}

Outdoor play and activities in the kindergarten and the surrounding natural landscape form an important part of kindergarten practice in the Nordic countries. This is rooted in a general Nordic kindergarten model in which children's self-initiated play and activities in varied outdoor surroundings are recognised as a part of the child's holistic learning (Halldén, 2011). Holistic learning means that a child's experiences, attained through body, movement and all the senses, all form a basis of learning processes. This is reflected in various ways in the Norwegian kindergarten curriculum (Sandseter \& Lysklett, 2017). The Norwegian Framework Plan for the content and tasks of kindergartens (Ministry of Education and Research, 2017) places emphasis among other things on the kindergarten enabling children to experience and explore diversity in nature. A relationship with nature is rooted in both Norwegian and Sami culture, where the natural environment has been, and remains, an important element in people's everyday life (Fasting, 2019; Myrstad, 2021). However, the Nordic kindergarten model, with its holistic approach to learning, finds itself under pressure.

Recent years have seen an increased focus, national and international, on learning in kindergarten (Biesta, 2013; Bingham \& Whitebread, 2018; Pettersvold \& Østrem, 2018). There is a tendency towards greater emphasis on cognitive development and academic skills relating to future schooling. This kind of learning pressure can occur at the cost of children's self-initiated and creative activities as a basis for learning (Ødegaard, 2021). A growing industry of standardised programmes and learning packages developed by commercial bodies can also lead to a lack of contextuality in understanding skills and knowledge and to children's interaction with their environments being neglected in favour of a standardised kindergarten content (Nygård, 2017). One way of resisting this tendency is to regard knowledge and exploration as relational processes in which learning is viewed as active, creative processes based on children's bodily and sensuous interaction with their surroundings. In order to develop the Nordic kindergarten model, Ødegaard (2021) promotes the idea that exploration should be brought to the fore and recognised as part of the signature pedagogy in the kindergarten. Creating a more nuanced view of children's interaction with their surroundings can help to broaden understanding of children's learning in this type of exploratory pedagogy.

\section{Children's dynamic relationships with their environment}

Gibson's affordance theory has been instrumental in describing the significance of children's direct contact with their environments (Fjørtoft, 2001; Kyttä, 2003; 
Sandseter, 2009). The affordance theory depicts how the physical environment in which people spend their time invite various actions and activities (Gibson, 1979). Kyttä (2003) uses this perspective as a basis for assessing whether environments can be considered child friendly. Sandseter (2009) highlights how different qualities and elements in outdoor environments provide children with opportunities to test boundaries and explore risks. Risky play is presented as an important element in the development of children's physical and mental health. This type of play is generated especially in an outdoor setting (Sandseter, 2009; Sandseter et al., 2017). Sandseter, Storli and Sando (2020) highlight the dynamic between children's play and their environments, showing how the child deploys the outdoor area of the kindergarten in line with their individual needs, intentions, and physical prerequisites. Sanderud, Gurholt and Moe (2019) show how children, through self-initiated play and activities in a winter landscape, create an understanding of themselves and of nature, suggesting that the skills developed by children during this interaction form part of their formation and lifelong learning.

Affordance theory is rooted in ecological perception psychology, in which the interaction between the individual and their environments is regarded as a dynamically interactive system. Gibson (1979) points out that perception is primarily directed towards people recognising affordances in their environments, before employing them. It is the perception of functionality and opportunities for action that are primary here. Objects appear as affordances in terms of things that can be tasted, lifted, hidden, slid on, and so on (Myrstad \& Sverdrup, 2016). In affordance theory, people are the active agents, able to exercise an influence upon and change their environments.

In the quest for sustainable practice, the relationship between children and nature has been afforded increasing interest in the light of post-humanistic and newmaterialistic theories. To a greater extent than in affordance theory, focus and attention is directed towards reciprocity in the dynamic interaction between children and a 'more-than-human' world (Comber, 2013; Malone, 2016; Myrstad et al., 2020; Somerville, 2015; Taylor \& Pacini-Ketchabaw, 2015). The learner and the environment are understood as an indivisible process, where different elements exercise a reciprocal influence on each other within a common world (Taguchi, 2010; Taylor \& Giugni, 2012). This understanding of an entangled world does not distinguish between people and their environments. This entanglement brings together ecological, socio-cultural, and material relationships. This might include the surface under our feet, the sky above our heads, the strength of the sun's rays, vegetation, the air being breathed: everything that living organisms absorb through life in the world (Ingold, 2011, p. 95). Relationships are key here, rather than people's intentions and functionality. A reciprocal relationship accommodates more parties than the human-social context, representing a challenge to the exclusive position of humans as active agents in the world (Blenkinsop, 2018; Dernikos \& Thiel, 2019). These perspectives contain echoes of deep ecology as well as of Indigenous philosophy in 


\section{P. Bartnces \& A. Myrstad}

which people and nature are regarded as relational beings (Absolon, 2010). Ingold's term 'correspondence' can be understood in the light of relational perspectives of this sort and can help fill out ideas of how children's learning emerges through being in and with the world.

\section{Correspondence - responding and being responded to}

Tim Ingold's correspondence concept can be used to highlight how children and their bodily movements constitute their environments and create knowledge. According to Ingold (2013) knowledge is not transferred as a package from one person to another, such as from educators to children or from one generation to another. It is rather through an individual's direct contact with their environments that knowledge grows and gradually becomes part of the person. Ingold regards this as a 'dance of animacy' between people and their environment (Ingold, 2013, p. 100-107). The aim of participating in this 'dance' is not to overcome, but to tune into and respond to the environment (Ingold, 2013, p. 7). Rather than seeking cause and effect between human and non-human parties, we should go beyond these binary ideas and look at this interaction as a life dance (Hackett, 2018). Taking a craftsman's work with his materials as an example, Ingold (2013) argues that the material changes as the craftsman works on it. The form of the material, such as clay, or in our case snow, is generated in a field of influences involving individuals, materials, and the environment in general (Ingold, 2013, p. 26-28). Weather, temperature, light, humidity, wind, and airborne particles are forces that affect the material at any one time. This means that when we encounter a material, 'it is matter in movement, in flux, in variation' with the result that 'this matter-flow can only be followed' (Deleuze \& Guattari, 2004, p. 450-451). The material world is not static and unchangeable but is subject to change when it is entangled with other elements (Powell \& Somerville, 2018). The active parties - the ceramicist that responds reciprocally with the clay, or the children who respond with the snow - must follow the dance with the material (Ingold, 2013). This is a way of tuning in to the 'language' of the material world, moment by moment. Unlike a materialtechnical interaction, correspondence with the world does not involve describing it or representing it, but responding to it (Ingold, 2013, p. 108). Repetitive sensuous and bodily movements in conjunction with a material allow gradual experience and knowledge to grow. This learning is not individual or cognitive but is generated through relationships.

Ingold proposes a close connection between the correspondence concept and attention. To correspond with the world entails being attentive (Ingold, 2018, p. 30). According to Masschelein (2010) attention involves opening to the world. He writes: 'Attention is precisely to be present in the present, to be there - in the present - in such a way that the present can present itself to me [...] As such, attention makes experience possible' (Masschelein, 2010, p. 48).

Attention is concerned with being fully present in the moment and responding to what is occurring in the here and now. It is attention, a sensitive presence, that yields 
action (Brooke, 2021). In this kind of understanding, engagement with the world is attentive rather than intentional. Engagement is not created in a world that is fully constructed but leads out into a world in creation. Attention thus acts to enable encounters with one's surroundings without intentions of functionality (Rautio \& Stenvall, 2019). According to Ingold (2000), this means that it is not necessary to involve mental constructions to be able to act in the world. People do not act in a fully constructed world but contribute to constructing it by means of direct involvement. This perspective promotes a view that everyone, including children, is an active co-creator of the world (Myrstad, 2018).

The concept of correspondence clarifies how human learning is sensuously and bodily entangled with the environment. The concept can serve as an approach to raising awareness of sensual impressions other than hearing and vision and can maintain children's bodily and sensuous methods of exploring the world. The approach can be regarded as an alternative to a pedagogy rooted in knowledge transferring and can help expand ideas of what children's learning and the role of the teacher can involve in a kindergarten context.

\section{Methodological approach}

The data have been gathered in connection with the project BarnSted, which is part of KINDknow - Kindergarten Knowledge Centre for Systemic Research on Diversity and Sustainable Futures. In this project, the focus is on children's encounters with different components in their local environments. Based on our micro-field work from an outdoor kindergarten, we refer, for instance, to children's encounters with snow. The kindergarten is in a semi-urban area on an island in the north of Norway. We took part in the outdoor periods in the area around the kindergarten for half a day each week from October to May, involving some 200 hours of field work in all. The outdoor area in question is varied, with upward and downward slopes, marshland, trees, bonfire sites and a traditional Sami tent called a làvvu. From October to May the ground was covered in snow of varying consistency and depth. The project participants consisted of 22 children aged 3-6 years, four members of educational staff and two researchers.

During our field work we were participating observers, either with or without a video camera. Our participation meant that we involved ourselves in the children's activities, got to know them and shared experiences through these processes (Ingold, 2018). Our observations consisted of attempting to see, hear and get a sense of what was taking place. We were inspired by the 'deep hanging out' method (Powell \& Somerville, 2018, p. 850), which entailed waiting for the children to take the initiative to invite us to play and to move together with them, have conversations, and so on. This is a 'practice of curiosity' in which we explore together (Haraway, 2015, p. 5). According to Haraway (2015), curiosity can grant participants unimagined possibilities and lead to unpredicted situations. We have accompanied the children in their 


\section{P. Bartnces \& A. Myrstad}

encounters with the snow and involved our own bodies to 'find ways to know-with' (Salmela \& Valtonen, 2019, p. 19). We have waded in the same snow, felt the cold on our bodies and the warmth from the bonfire and were exposed to wind and weather in the same way as the children. This presence was the basis on which we shared experiences and engagement with the children (Johansson \& Løkken, 2014, p. 51). This sharing of experiences can be understood as an interweaving of experiences, such that it can be regarded as a correspondence.

During the first few months we took part without a camera and established a relationship with the children and the staff. After repeated meetings the children showed trust in us and expectations of us as 'different' adults. Our presence, both with and without the video camera, meant that some of the children took us along with them as they moved across a larger area, or stayed for a long time in one part of the grounds. On some occasions the children turned their backs on us and walked away. We took this as a signal that the children did not want our presence, and we respected this. When using the video camera, a handheld camera with an open display was used by the researchers and held at the children's height. This prevented our faces from being hidden behind the camera, allowing us as researchers to communicate with the children and staff (Myrstad et al., 2020). The video camera thus functions as a third eye instead of being the only eye (Sinding-Larsen, 1992). We have consistently avoided using zoom during the video filming, specifically in order that the children were always able to see what the lens was pointing at. This gives them an element of choice about how they will relate to the camera. This is particularly significant in relation to children's opportunity to acquiesce or refuse to be filmed (Myrstad, 2009). Even though the parents have given informed consent to the research and video filming of their children, we have an ethical responsibility as researchers to meet the children with sensitivity and respect. For us, this has meant that video filming and participation in some circumstances was interrupted due to ethical considerations.

The data material consists of field notes, weather observations and video clips. Selected video clips were shown regularly to the staff as a basis for conversations and reflection. The data material used in this article consists of transcriptions from video clips from our joint field work.

\section{Analytical techniques}

We have repeatedly reviewed the data material and combined video clips with weather reports and field notes. When reviewing the video clips, we have recalled our physical and sensuous experiences (Pink, 2009) while reflecting over what has been captured through the lens. The basis of our analysis has been to explore how children's bodies, through their movements and senses, 'reciprocate' with the environment. This mutual process is constant. This is particularly clearly visible in the data material in terms of snow conditions that are shaped by children's movements, while at the same 
time shaping those same movements. The first two examples in the article have been chosen to illustrate this reciprocal correspondence. The final example demonstrates how an educator and researcher mediate the children's correspondence in their direct contact with snow.

\section{Moving across a fragile snow crust}

It is $10^{\text {th }}$ May and some parts of the kindergarten's outdoor area are free of snow, while there is still $15 \mathrm{~cm}$ of snow in the shaded northern-facing slopes. During the past week, the average snow depth has reduced, according to the weather forecast, by nearly $20 \mathrm{~cm}$, disappearing altogether in some places. The snow is rotten, but the sharp cold at night has formed a thin crust that will bear a light weight. Researcher Pernille is together with two children, video filming the children as they make their way up onto a small, snow-covered area.

Nina (5) and Rasmus (4), wearing rain clothes and Cherrox boots, are walking towards an area covered in snow. They each have a spade in the hand. Rasmus jumps down onto the snow-covered area, landing on his knees, and digs in the snow with his spade. When Nina begins to move down the snowy slope, Rasmus too stands up and starts walking. The crust supports his weight only for the first three steps, after which he begins to sink through it every time he puts his right foot down. "Ah! I'm sinking so deep into it!" he says to Nina. He takes a step with his left foot and then carefully puts his right foot down. The crust holds. He remains standing for a couple of seconds before continuing across the snow and balancing on the crust with light steps.

May snow has varying qualities, depending on the daily temperature, location and sun and wind conditions. On the snow's crust, Rasmus needs to adjust his bodily response to the unstable snow from step to step. The snow initially gives way under Rasmus' weight, with his right foot penetrating the crust several times and sinking through the rotten snow before reaching solid ground. His response is both verbal and physical. It is physical in the sense that he adjusts his movements by leaning to the side and placing his body weight more on the left side. Because most of his body weight is on the left, Rasmus' walk acquires a limping rhythm. This movement is related to the snow - a surface that varies with every step that Rasmus takes. His adjustments are a direct response or 'reply' to how the snow is responding to his movements. When the crust responds by giving way to the weight of his steps, Rasmus responds by distributing his weight differently. Rasmus' movements thus transcend the individual, being shaped in relation to a varied snow cover.

\section{Wading through deep snow}

This example is from a video clip from the $8^{\text {th }}$ of November. The weather forecast from the Norwegian meteorological service Yr.no shows a snow depth of $65 \mathrm{~cm}$ and a temperature of $-8^{\circ} \mathrm{C}$. The previous week has seen around $30 \mathrm{~cm}$ of new snow. The area beside the kindergarten has not been visited since the previous week's snowfall 
and there are no visible signs of activity in the snow. It is just before the children's lunchtime.

Erik (4) rolls down a short steep hill and lies on his back in about $30 \mathrm{~cm}$ of new snow. Researcher Anne is accompanying Erik and following him with a camera. A member of staff calls that all the children must come to the assembly point to return to the kindergarten. The boy takes aim and throws himself over to one side, before getting up with the aid of his arms, which have sunk some way into the snow. Upright, he takes a few steps, for which he lifts his knees and thighs to almost a $90^{\circ}$ angle, while leaning forward. 'I can always walk in deep snow', he says. When he reaches some twigs, his foot sinks far down into the snow. His body follows his foot, and he leans his upper body to one side to regain his balance. He continues up the hill that he rolled down, walking in his own 'rolling tracks' while his feet slip. He creates new tracks so that his feet reach solid ground and can get a grip. The foot that he places weight on sinks down through the snow again and he slips once more. He takes a break and looks back at Anne. Erik focusses on the foot that has traction, leans forward, and takes a few steps, lifting his knees high up above ground level. $\mathrm{He}$ takes another three steps and then takes a break. In the steepest section he pauses after every other step.

Erik's goal appears to be to make it up the hill, but the snow is providing resistance that affects his direction, rhythm, and mobility. With every step, Erik needs to tune in and respond with bodily movements to the varied conditions underfoot in the deep snow, which in places reaches right up to his thigh. Erik follows the 'dance' (Ingold, 2013 , p. 108) with the forces of the snow, created by the wind, light conditions and earlier - but now invisible - tracks under the snow. The snow's quantity, depth and consistency, topology and gravity all work together with Erik's physical movements. Together, these affect the direction in which Erik's body moves and what tracks he leaves. The resulting tracks do not lead in a straight line but show how he was driven forwards and backwards in the snow. Gravity in the upward slope and in the snow influence the rhythm of Erik's movements. It is physically heavy to lift the whole of one's foot while the upper body is leaning forwards and the arms projected outwards to maintain balance. This means that Erik must take breaks several times and his pace gains a staccato rhythm.

\section{Exploring snow crystals}

This example comes from a video take on the same November day as the above example. Children, staff, and researchers are on their way from the outdoor area into the kindergarten. Researcher Anne walks along the trodden-down path together with an educator and three children (two boys - Kåre and Per - and a girl - Mia - all of them 4 years old). The cold has led to the formation of snow crystals underfoot and these have fastened themselves around straw and twigs.

The two boys are in the lead. They halt at flat ground to wait for the others. The educator, who is walking behind them, points, saying: 'Look at the frost on the straws!' The educator bends down, removing his gloves, and puts some snow crystals into his hands. Kåre and Per kneel and bend over the straws. 
The children and researcher say at the same time: 'Oh!' The educator puts some flakes of snow crystal onto Kåre's mitten.

Kåre puts out his tongue, puts the snow crystals in his mouth and says: 'Mmm.'

Educator: They're huge!

Per: $\quad$ Can I have one?

The educator gives Per some snow crystals, adding: 'Why are they like that, do you think?'

Kåre replies 'Because it's so cold.'

Educator: Because it's so cold, but what makes it cold?

Researcher: They were so pretty as well.

Mia: They were so pretty.

Researcher: There's more over here. I'll have to get a picture of them.

Everyone moves a bit further over the flat ground to some other straws.

Educator: All the straws are full.

Researcher: Think that every snow crystal is different, just imagine it!

The two boys crouch down in the snow and take hold of the straws.

Per: We can just eat them.

Researcher: Can you eat them as well, oh?

Per takes the straw with the snow crystals over to Kåre, who is sitting with his tongue sticking out.

Kåre: $\quad$ Ouch, they're so sharp!

Researcher/educator: Are they sharp, too?

Kåre bends right down to the straws, sticks his tongue out towards the snow crystals and says 'Oouch!'

Per removes snow crystals from the straws with his mitten, before putting the crystal-covered mitten to his mouth.

Per: Why are they so sharp?

Per has crouched down and put out his tongue three times to get a snow crystal in his mouth.

Kåre: $\quad$ Don't know.

Per: $\quad$ Perhaps because they're so frozen?

In this example, time and space have been dedicated to stopping and exploring the snow crystals that have formed on the straws. The educator directs the children's awareness towards the snow crystals. Out of enthusiasm to transmit knowledge and values to the children, the educator asks questions the answers to which are familiar. The researcher comments about aesthetics and qualities, depicting the aspects that can be valued about the snow crystals. Educator and researcher both base their comments on previous knowledge and experience that they are sharing with the children. The children's sensuous, direct encounter with the snow crystals, however, provide 


\section{P. Bartnces \& A. Myrstad}

access to another source of knowledge. For instance, the touch of the tongue against the snow crystals provides the children with an insight into the sharp texture of the snow crystals. This correspondence indicates that the children's direct engagement with the snow crystals can generate a different type of knowledge than that focussed on by the researcher and educator. This kind of sensuous, spontaneous experience cannot be taught directly by the educator or researcher. The surroundings are functioning here as a 'co-teacher' (Blenkinsop, 2018).

\section{Discussion: Learning in and with snow}

The first two examples illustrate how forces in the snow influence the rhythm and flow of the children's movements. In that the local environment is affected by seasonal variations, the children and the snow are not the only relevant factors: the interaction includes other children, the researchers, the camera, the temperature, precipitation, air humidity, light conditions and choice of clothes and footwear. Walking on, touching, and tasting snow are ways of showing awareness of the world - of being fully present in the moment. In their encounters with the various snow conditions, the children interact with the terrain, the path, the wind, gravity, the texture, and consistency of the snow and with other elements. They focus their awareness on what they discover in the encounters by tuning in and responding through their large or small movements (Ingold, 2018). At the same time, the way the surface underfoot responds to the children's movements is a determining factor in shaping the next movement. In a correspondence of this sort, the ground is more than just a passive background, a space available for activity. Moving in this way can be regarded as a collective action between 'human' and 'non-human-others' (Hackett \& Rautio, 2019), and as something more than a phenomenon related to children's intentional actions.

The concept of correspondence can be a tool for examining the learning that takes place during these reciprocal processes. We regard this as a form of in-depth learning that is concerned with tuning in and responding to the forces within which the child is entangled. The goal in this kind of reciprocal interaction is not to overcome the environment but to master a sensitive interaction with it. Knowledge is generated slowly and gradually, is open, relational and is formed when the children's movements follow the flow in the snow (Ingold, 2013). This kind of knowledge is difficult to quantify, standardise, or generalise. It is learning that is constituted by being in and with the environment, rather than through individual cognitive learning about the environment (Ingold, 2018; Taylor, 2017). In the light of an integrated view of holistic learning, the concept of correspondence can be a means of identifying and describing how bodily and sensuously acquired knowledge emerges as a part of a child's exploration in and with the world. It is important to highlight and value this sort of learning and knowledge on equal terms with cognitive and academic skills, even though it is not always functional or internal - but rather unpredictable, improvisational, and in becoming (Harwood et al., 2019). 
A stated pedagogic goal for the kindergarten is to enable an exploratory practice (Ministry of Education and Research, 2017). Questions could be raised about whether the educator and researcher in the final example are genuinely exploring together with the children or whether they are subconsciously assuming the role of better-informed adults who are expected to be teaching. In the examples with the snow crystals, the researcher and educator have an opportunity to acquire information beyond their existing knowledge, but this is not much exploited in this instance. This can point back to a traditional pedagogy role in which the educator's intention is to transfer already-established knowledge to the child (Ingold, 2018) in the form of transmitting academic and conceptual learning. A greater focus on the relationships between children and their environments will require being open to the opportunities inherent in unpredictable and ambiguous circumstances and can help to go beyond the boundaries of traditional learning practices (Powell \& Somerville, 2018, p. 3).

Children's correspondences with their environments will occur whether kindergarten staff or researchers are paying attention to them at the time. This may seem like an echo of the romantic notion that children learn, experience things, and gain mastery simply by existing undisturbed in nature. We nevertheless promote the significance of appreciating and paying attention to the kind of physical and sensuous interactions we have described, simply because they can generate other skills and understandings. The concept of correspondence can be a tool for identifying these processes, which will otherwise be ignored or overlooked. In terms of kindergarten practice, this will primarily entail setting aside time and space for the emergence of this kind of interaction (Myrstad et al., 2020). A further step in terms of pedagogic practice as well as in a research process would be to question where the focus of attention lies and what consequences can derive from redirecting awareness from the individual to relationships (Brooke, 2021, p. 187).

Paying attention to correspondence is about more than just observing. It is a matter of participating, in the form of being open to learning and exploring together with the children (Ingold, 2018, p. 61). In situations that are driven by children's exploration, as in the instances with the snow crystals, this requires that the researcher and educator keep their knowledge to themselves and do not direct what is to be appreciated or paid attention to (Green \& Somerville, 2015). In this kind of perspective, the educator's role will be to lead the child out into the world and to participate in their exploration, rather than transmitting information about the world to the child (Ingold, 2018). This approach to teaching and learning is a reminder that learning can be more than simply transmitting predefined knowledge (Myrstad \& Sverdrup, 2019). Highlighting these processes as significant can be an element in what Ødegaard (2021) identifies as the signature pedagogy of the kindergarten, in which exploration is the primary feature in developing sustainable practices. The development of a sensitive interaction between people and their environments has been described as key to the development of sustainable perspectives (Lynch \& Mannion, 2021; Powell \& 


\section{P. Bartnces $\mathcal{E}$ A. Myrstad}

Somerville, 2018). In the light of this, the concept of correspondence can be a tool with which to explore sustainable practice in the kindergarten.

By viewing children's learning as something that is entangled with their environments, the complexities of how they experience the world will be made more visible (Gallacher, 2016). The world - or in this instance the snowscape - is in formation, as new relationships arise between other living organisms, between weather and conditions (Thompson, 2014). This complexity allows us to capture a diversity of relationships of which people and children at any one time form a part (Myrstad, 2018). The perspective also highlights the significance of giving children opportunities to experience varied landscapes and different seasons and weather conditions when provision is made for children to go their own way and to be co-creators of their own knowledge. Given an attitude that everybody can learn in a learning situation, even educators and researchers can acquire new knowledge and understanding through such encounters. And in this way, we can perhaps find the answer to what a snow crystal tastes like?

\section{Conclusion}

Enabling children to learn in and with their environments requires an acknowledgement that knowledge is not the exclusive domain of humanity (Weldemarian, 2020), but can also be acquired in the correspondence between different elements of our surroundings, by means of large or small physical or sensuous encounters. The concept of correspondence can help educators perceive such learning processes and thus to explore and value them. For educators, this can entail a shift in attention from the child as an individual towards what occurs in the relationship between the child and their environments. This is a dance of life, which over a period can provide a deeper understanding of how individuals and their environments are entangled in a common world.

\section{Acknowledgement}

The article is based on a project in KINDknow, funded by RCN, Project code: 275575. The publication charges for this article have been funded by a grant from the publication fund of UiT The Arctic University of Norway.

\section{Author biography}

Pernille Bartnas is a Lecturer in early childhood teacher education at the Department of Education, The Arctic University of Norway. Pernille is interested in place-based education related to early childhood issues. 
Anne Myrstad is an Assistant Professor at the Department of Education, The Arctic University of Norway. Anne is interested in placed-based education related to sustainability issues in early childhood. She researches mostly in kindergartens, in collaboration with children and staff, employing qualitative methods.

\section{References}

Absolon, K. (2010). Indigenous wholistic theory: A knowledge set for practice. First Peoples Child E Family Review, 5(2), 74-87. https://fpcfr.com/index.php/FPCFR/article/view/95

Biesta, G. J. J. (2013). The beautiful risk of education. Paradigm Publication.

Bingham, S., \& Whitebread, D. (2018). School readiness in Europe: Issues and evidence. In M. Fleer, \& B. van Oers (Eds.), International handbook of early childhood education (pp. 363-391). Springer.

Blenkinsop, S. (2018). Six touchstones for wild pedagogies in practice. In B. Jickling, S. Blenkingsop, N. Timmerman, \& M. De Danann Stika-Sage (Eds.), Wild pedagogies (pp. 77-107). Palgrave Studies in Educational Futures.

Brooke, A. H. (2021). Renewing a craftmanship of attention with the world. Studies in Art Education, 62(2), 184-190. https://doi.org/10.1080/00393541.2021.1896266

Cele, S. (2019). A tale of two trees: How children make space in the city. In P. Rautio \& E. Stenvall (Eds.), Social, material and political constructs of Arctic childhoods: An everyday life perspective (pp. 1-16). Springer.

Comber, B. (2013). Literacy for a sustainable world. In S. White, B. Comber, A. Simpson, \& P. Freebody (Eds.), Language, literacy and literature (pp. 26-48). Oxford University Press.

Deleuze, G., \& Guattari, F. (2004). A thousand plateaus: Capitalism and schizophrenia (B. Massumi, Trans.). Continuum.

Dernikos, B. P., \& Thiel, J. J. (2019). Early childhood environmental education and the posthuman "turn": Why knowing as "we" go matters. The International fournal of Early Childhood Environmental Education, 7(1), 4-6.

Eira, I. M. G., Oskal, A., Hanssen-Bauer, I., \& Mathiesen, S. D. (2018). Snow cover and the loss of traditional indigenous knowledge. Nature Climate Change, 8(11), 928-931. https://doi.org/10.1038/s41558-018-0319-2

Fasting, M. L. (2019). Barns utelek. Universitetsforlaget.

Fjørtoft, I. (2001). The natural environment as a playground for children: The impact of outdoor play activities in pre-primary school children. Early Childhood Education fournal, 29(2), 111-117. https://doi. org/10.1023/A:1012576913074

Gallacher, L. A. (2016). Theorizing young children's spaces. In A. Farrell, S. L. Kagan, \& E. K. M. Tisdall (Eds.), The SAGE handbook of early childhood research (pp. 118-132). Sage.

Gibson, J. J. (1966). The senses considered as perceptual systems. Houghton Mifflin.

Gibson, J. J. (1979). The ecological approach to visual perception. Lawrence Erlbaum Associates.

Green, M., \& Somerville, M. (2015). Sustainability education: Research practice in primary schools. Environmental Education Research, 21(6), 832-845. https://doi.org/10.1080/13504622.2014.923382

Hackett, A. (2018). Barn, sted, tid, bevegelse: På sporet av litteratur om romlig teori og dens relevans for små barn. In A. Myrstad, T. Sverdrup, \& M. B. Helgesen (Eds.), Barn skaper sted - sted skaper barn (pp. 17-27). Fagbokforlaget.

Hackett, A., \& Rautio, P. (2019). Answering the world: Young children's running and rolling as more-thanhuman multimodal meaning making. International fournal of Qualitative Studies in Education, 32(8), 1019-1031. https://doi.org/10.1080/09518398.2019.1635282

Harwood, D., Barratt, J., \& Collier, D. (2019). Entanglements in the forest: The orange GoPro camera and the children who wear them. International fournal of Early Childhood Education, 7(1), 57-72.

Halldén, G. (2011). Bardomens skogar: Om barn og natur och barns natur. Carlsson Bokförlag.

Haraway, D. (2015). A curious practice. Angelaki. Fournal of the Theoretical Humanities, 20(2), 5-14. https://doi. org/10.1080/0969725X.2015.1039817

Ingold, T. (2000). The perception of the environment: Essays on livelihood, dwelling and skill. Routledge.

Ingold, T. (2011). Being alive. Essays on movement, knowledge and description. Routledge.

Ingold, T. (2013). Making: Anthropology, archaeology, art and architecture. Routledge.

Ingold, T. (2018). Anthropology and/as education. Routledge. 


\section{P. Bartnces \& A. Myrstad}

Johanssson, E., \& Løkken, G. (2014). Sensory pedagogy: Understanding and encountering children through the senses. Educational Philosophy and Theory, 46(8), 888-897. https://doi.org/10.1080/00131857.2013. 783776

Kyttä, M. (2003). Children in outdoor contexts. Affordances and independent mobility in the assessment of environmental child friendliness. [Doctoral dissertation]. Aalto University.

Lynch, J., \& Mannion, G. (2021). Place-responsive pedagogies in the Anthropocene: Attuning with the morethan-human. Environmental Education Research, 27(6), 864-878. https://doi.org/10.1080/13504622.2020. 1867710

Masschelein, J. (2010). E-ducating the gaze: The idea of a poor pedagogy. Ethics and Education, 5(1), 43-53. https://doi.org/10.1080/17449641003590621

Malone, K. (2016). Posthumanist approaches to theorising children's human-nature relations. In K. Nairn, P. Kraftl, \& T. Skelton (Eds.), Space, place and environment: Geographies of children and young people (pp. 185-206). https://doi.org/10.1007/978-981-287-044-5_14

Myrstad, A. (2009). Kunnskapsutvikling gjennom linsa. In B. Groven, T. M. Guldal, O. F. Lillemyr, N. Naastad, \& F. Rønning (Eds.), FoU i praksis 2008. (pp. 285-293). Tapir Akademisk Forlag.

Myrstad, A. (2018). Å bebo verden ved å bevege seg gjennom den. In A. Myrstad, T. Sverdrup, \& M. B. Helgesen (Eds.), Barn skaper sted - sted skaper barn (pp. 29-44). Fagbokforlaget.

Myrstad, A. (2021). Samiske perspektiver i en barnehages hverdagsliv. In K. J. Horringmo, \& K. T. Rosland (Eds.), Fagdidaktikk for SRLE (pp. 202-212). Cappelen Damm Akademisk.

Myrstad, A., \& Sverdrup, T. (2016). Første-fots-erfaringer gjennom vandring - de yngste barnas samspill med omgivelsene i barnehagen. In T. Gulpinar, L. Hernes, \& N. Winger (Eds.), Blikk fra barnehagen (pp. 97-115). Fagbokforlaget.

Myrstad A., \& Sverdrup, T. (2019). De yngste barna som vegfarere i barnehagen. Nordic Early Childhood Education Research fournal, 18, 1-12. https://doi.org/10.7577/nbf.2622

Myrstad, A., Hackett, A., \& Bartnæs, P. (2020). Lines in the snow, minor paths in the search for early childhood education and planetary wellbeing. Global Studies of Childhood, 1-13. https://doi.org/10.1177/ 2043610620983590

Norwegian Ministry of Education and Research (2017). Framework Plan for the Content and Tasks of Kindergartens. Oslo: Norwegian Ministry of Education and Research.

Nygård, M. (2017). Barnehagen som leringsarena i endring. Politiske ideologier og barnehagelcererens fortolkninger [Doctoral dissertation]. Norges teknisk-naturvitenskapelige universitet.

Pettersvold, M., \& Østrem, S. (2018). Profesjonell uro. Barnehagelcererens ansvar, integritet og motstand. Fagbokforlaget.

Powell, S. J., \& Somerville, M. (2018). Drumming in excess and chaos: Music, literacy, and sustainability in early years learning. Fournal of Early Childhood Literacy, 20(4), 839-861. https://doi.org/10.1177/ 1468798418792603

Pink, S. (2009). Doing sensory ethnography. Sage.

Pink, S. (2011). From embodiment to emplacement: Re-thinking competing bodies, senses and spatialities. Sport, Education and Society, 16(3), 343-355. https://doi.org/10.1080/13573322.2011.565965

Rautio, P., \& Stenvall, E. (2019). Social, material and political constructs of Arctic childhoods: An everyday life perspective. Springer.

Sanderud, J. R., Gurholt, K. P., \& Moe, V. F. (2019). 'Winter children': An ethnographically inspired study of children being-and-becoming well-versed in snow and ice. Sport, Education and Society. 25(8), 960-971. http://doi.org/10.1080/13573322.2019.1678124

Sandseter, E. B. H. (2009). Affordances for risky play in preschool: The importance of features in the play environment. Early Childhood Education fournal, 36(5), 439-446. https://doi.org/10.1007/s10643-0090307-2

Sandseter, E. B. H., Little, H., Ball, D. J., Eager, D., \& Brussoni, M. (2017). Risk and safety in outdoor play. In T. Waller, E. Ärlemalm-Hagsér, E. B. H. Sandseter, L. Lee-Hammond, K. Lekies, \& S. Wyver (Eds.), The $S A G E$ handbook of outdoor play and learning (pp. 113-126). Sage.

Sandseter, E. B. H., \& Lysklett, O. B. (2017). Outdoor education in the Nordic region. In C. Ringsmose, \& G. Kragh-Müller (Eds.), Nordic social pedagogical approach to early years. International Perspectives on Early Childhood Education and Development (Vol. 15). Springer. https://doi.org/10.1007/978-3-319-42557-3_7

Sandseter, E. B. H., Storli, R., \& Sando, O. J. (2020). The dynamic relationship between outdoor environments and children's play. Education 3-13. Advance online publication, https://oi.org/10.1080/03004279.2020. 1833063 


\section{Knowing-with-snow in an outdoor kindergarten}

Salmela, T., \& Valtonen, A. (2019). Towards collective ways of knowing in the Anthropocene: Walking-with multiple others. Matkailututkimus, 15(2), 18-32. http://doi.org/10.33351/mt.88267

Sinding-Larsen, H. (1992). Eksternalisering. Norsk antropologisk tidsskrift, 3, 67-78.

Somerville, M. (2015). Children, place and sustainability. Palgrave Macmillan.

Springgay, S., \& Truman, S. E. (2018). Walking methodologies in a more-than-human world: WalkingLab. Routledge.

Taguchi, H. L. (2010). Bortenfor skillet mellom teori og praksis. Fagbokforlaget.

Taylor, A. (2017). Beyond stewardship: Common world pedagogies for Anthropocene. Environmental Education Research, 23(10), 1448-1461. https://doi.org/10.1080/13504622.2017.1325452

Taylor, A., \& Giugni, M. (2012). Common worlds: Reconceptualising inclusion in early childhood communities. Contemporary Issues in Early Childhood, 13(2), 108-119. https://doi.org/10.2304/ciec.2012.13.2.108

Taylor, A., \& Pacini-Ketchabaw, V. (2015). Learning with children, ants, and worms in the Anthropocene: Towards a common world pedagogy of multispecies vulnerability. Pedagogy, Culture E Society 23(4), 507-529. https://doi.org/10.1080/14681366.2015.1039050

Thompson, D. (2014). Caring, dwelling, becoming: Stories of multiage child care. University of Victoria.

Weldemariam, K. (2020). Learning with vital materialities: Weather assemblage pedagogies in early childhood education. Environmental Education Research, 26(7), 935-949. https://doi.org/10.1080/13504622.2020. 1761300

Ødegaard, E. E. (2021). Reimagining “collaborative exploration" - a signature pedagogy for sustainability in Early Childhood Education and Care. Sustainability, 13(9), 1-18. https://doi.org/10.3390/su13095139

Änggård, E. (2016). How matter comes to matter in children's nature play: Posthumanist approaches and children's geographies. Children's Geographies, 14(1), 77-90. https://doi.org/10.1080/14733285.2015. 1004523 